\title{
On student movements in the decay of the Estado Novo
}

\author{
Miguel Cardina Centre for Social Studies, \\ University of Coimbra
}

\begin{abstract}
Throughout the period of nearly two decades nicknamed the 'long sixties', youth practices and speeches obtained their own autonomy and frequently reached the top of radical criticism regarding the socio-economic, cultural and political models that were in place. Mainly spreading from universities, these dynamics articulated themselves at certain times quite significantly with specificities according to each country's own reality. This article intends to testify to the main characteristics of the student protests that took place in Portugal in the final years of the Estado Novo (New State, 1932-74) and also to note the distances and approaches between these student movements and those that were developing during that time in the democratic western countries.
\end{abstract}

In the late 1960s, the process of political and cultural dissidence that had permeated Portuguese student circles from the end of the previous decade (visible in the constant election of left-wing lists to student associations, and the politicisation of student discourses and practices) converged with the atmosphere of international ferment and rebellion that Robert Frank called, in a somewhat exclusive reference, 'l'espace 68' (Frank 2000: 31). As Arthur Marwick (1998) suggests in the sub-title to his important work on the subject, this period witnessed what was effectively a cultural revolution that profoundly transformed the fields of culture, politics and morality. These changes emanated largely from the universities, in some cases taking on specific characteristics in accordance with different national contexts. This text intends to investigate the student protests that took place in Portugal during the final years of the Estado Novo. First, however, it is important to mention some of the differences between these student movements and those that were developing over the same period in the democratic western countries.

\section{Particular receptions}

In Portugal, the reception of these new trends was filtered by social conditions at the time. Political repression, slow urban development and the extension into all domains of daily life of the conservative Catholic morality meant the more radical practices generated by the 'anti-disciplinary protest' of the period found it difficult to take root (Stephens 1998). Attitudes of a post-materialist nature, connected to

\section{Keywords}

contemporary history

Estado Novo

student movements

$1960 \mathrm{~s}$

political radicalism 
questions of consumption, identity or minorities, were not really appropriate in what sociologist Adérito Sedas Nunes in 1964 defined as a 'dualist society in evolution', split between traditional and modern values and behaviour (Nunes 2000: 25-84).

Even within the multifaceted opposition camp, hedonistic and antihierarchical attitudes were considered incompatible with the spirit of abnegation required by the anti-fascist cause and with the conspiratorial prudence the political situation imposed upon all who wished to fight in an organised fashion against the regime. For those who were engaged in the political struggle, these postures were seen much more as an individualistic consequence of a capitalism (or, when they adopt radical postures, as a 'childish disease of communism', to use Lenin's words) than a refusal of the bourgeois way of life. In fact, employing Paul Berman's recent typology of the movements of the late 1960s, we can find more 'old fashioned sectarian Marxism' than 'modernised Marxism', and much more than 'inconsequent libertarianism' (Berman 2005: 42-4).

This explains, for instance, the overly critical review to António José Saraiva's book Maio e a crise da civilização burguesa (May and the crisis of bourgeois civilisation) (1970), which hopes to bring to the country the debate on the theories that entertain the emerging left wing. From correspondence that recently came to light, dated at the end of 1967, Saraiva, who was at the time living in Paris, confessed to his friend Óscar Lopes that the overthrow of the capitalist model was not just dependent upon changes to the economic infrastructure. As he notes, 'even in the socialist countries a bourgeois model type was respected, a model of the sober, stern, smart-looking man', a model that was now being radically questioned (Neves 2004: 175). This is the tone that is set in the first pages of the book, in which Saraiva speaks of the 'crisis of bourgeois civilisation' and not of the 'bourgeoisie', because what it is about 'is not a crisis of the social-economic class denominated by that name, but the crisis of a civilisation - of all the groups and classes of a civilisation that seems to rightly deserve the name bourgeois' (Saraiva 1970: 15).

In Portugal in 1971, the Communist Party (PCP - Partido Comunista Português) published Radicalismo pequeno-burguês de fachada socialista (Petitbourgeois radicalism with a socialist façade). Written by the party's general secretary, Álvaro Cunhal, this was an attack aimed at the 'fugitives', 'verbalists' and 'teachers of the revolution' for their inconsequential practices and theories that, 'consciously or not, produce the game of fascism'. May and the crisis of bourgeois civilisation and its author were directly attacked, which was not unrelated to the fact that Saraiva was already an established figure in the opposition milieu that was connected, shortly before, with the PCP. After citing the text, Cunhal asserts that they are "wrong and highly harmful... those conceptions that some seek to spread (flattering the students' dignity and self-esteem), that the student movement is the vanguard of the revolutionary struggle' (Cunhal 1974: 169).

The controversy is also expanded to the centre of the opposition's intelligence, pasted in a number of comments that come to light in the most diverse press. In O Tempo e o Modo, a publication whose ideological stance shifted from progressive Catholicism to Maoism during the 1970s, Sebastião Lima Rego accused Saraiva of 'irrationalism' and 'strictly subjective 
digressions' (Rego 1971). In 1973, a compilation of texts strongly critical of the thesis advanced in May and the crisis of bourgeois civilisation was published, with most of the texts professing their faith in the vigour of the traditional concept of class struggle and the role of the proletariat as a historical subject. Daniel Paulo contrasts the Dicionário crítico (Critical dictionary), written by Saraiva in 1960, with his new ideas, emphasising the points of disagreement. Jofre Amaral Nogueira, in turn, considers it a 'highly unfortunate book', in which the author replaces 'necessarily laborious social analysis ... with a scenario of a paper painted in broad lines' (Coelho 1973: 84). José Pacheco Pereira centres the book 'between simple and ordinary anti-Stalinism and the consequent lowly libertarian anarchism' (Coelho 1973: 92).

Despite this criticism, Saraiva's ideas drew attention to the original attack that was now being aimed at the post-industrial society and the 'bourgeois mentality'. In fact, and as stressed by Boaventura de Sousa Santos, already with larger critical estrangement, the student movement of the 1960 s can be characterised as the great articulator of the politicalcultural crisis of Fordism, due to its innovative features: an anti-productivist and post-materialist model; the denunciation of oppression in both the workplace and within the realm of social reproduction (family, school, etc.); the emergence of a new type of conflict, with the consequent end to workingclass hegemony in the struggle for social emancipation; and the emergence of youth as a new historical subject (Santos 1996: 215).

Receptive to these arguments, the Portuguese student movement did not, however, train them on political objectives. In this respect, it is curious that António Reis, defending the theoretical formula of Marcuse in a debate with Vital Moreira in Seara Nova, considered the issues faced by the German philosopher to be 'remote' from the Portuguese reality (Reis 1974). In truth, both the regime and the colonial war were targets of struggle that immediately shaped both the critical speech as well as the political intervention of Portuguese youth. As already noted, the "mystical hippy movement' has never been the subject of symbolic construction in the country (Resende and Vieira 1992: 134). Despite this, some traces, in line with a more combative 'spirit of the times', had practical expression in Portugal.

In fact, a significant portion of the country's youth gradually absorbed the reverberations of this new atmosphere of insubordination and informality. Although anti-imperialist and anti-capitalist tendencies predominated over the more counter-cultural and festive aspects of political activism, the 'world culture' that gradually took shape during the 'long sixties' did manage to manifest itself in Portugal, contributing to the construction of a world view based upon a vague attraction to 'otherness' and the affirmation of 'social commitment' as a duty of citizenship (Jameson 1984; Bebiano 2003a).

Music, cinema, literature, comic strips, theatre, even clothing served as vehicles for this challenge to the political and social status quo, a trend that could be seen in Prague, Berkeley, Paris, São Paulo and Rome, as well as in Lisbon. It made explicit the kind of movement that was under way a movement of educated urban youth and of those close to them, who were no longer content to perceive themselves as an amalgam of subjects in an unfinished process of social integration, but instead began to act, 
think and feel for themselves, following models that were almost always out of step with the regime's isolationist rhetoric and the dominant features of moral conservatism.

Fernando Pereira Marques underlines that in Portugal, 'letting the beard grow - only slightly - in a childlike imitation of The Beatles, became an act of courage and rebellion' (Marques 2005: 26). A cultural act such as the Vilar de Mouros Festival, a sort of home-made Woodstock in a Minho village in August 1971, or the first jazz festival in Cascais, in November of the same year, demonstrates the existence of tastes and behaviours that were far removed from the dominant moral and political censorship. In Cascais, Charlie Haden was actually arrested, interrogated and expelled from the country after dedicating a theme by Che Guevara on the movements of African liberation. A similar example is recalled by Joana Lopes. In June 1968, French dancer and choreographer Maurice Béjart's show in the Coliseu dos Recreios ended with an enthusiastic ovation when, in the last scene, news about struggles and revolts are read in several languages and the slogan 'make love, not war' is repeated (Lopes 2007: 118).

A significant part of youth, namely the students, was trying to exercise the 'possible internationalism': travelling to compare. In a recent series of interviews conducted with some scientists on their university courses, António Coutinho recalls that 'a fringe of the university population was in contact with people who were outside, who lived the May '68, who were in Germany, in France, some even in the United States', stating that he had gone to Paris in the aftermath of May 1968, moved by the influence of the situationists (Massada 2002: 52). The Lisbon Higher Technical Institute's academic association even held a 'reasonable tourist business', which chartered 'a large number of aircrafts in Europe every year', recalls Mariano Gago (1998), president of the association in 1969.

The lure of 'abroad' assumed a special dimension, not only because it represented a reversal of the value of self-reliance promoted by the Estado Novo, but also because it was almost always an opportunity to reject the regime's colonialism and authoritarianism. José Cândido Rodrigues, described his impressions of a journey to the Netherlands, portraying Amsterdam as a 'progressive' city that 'protests against American intervention in Vietnam' and in which there is plenty of 'graffiti against fascism', and where the political engagement is a constant concern at the universities (Rodrigues 1968: 6).

\section{Roots of dissidence}

This change was particularly visible in the universities. Although the traditional image of the student (male, from a privileged social background and destined to occupy an important role within the social hierarchy) was already being eroded by the 1960s, the early association movement was very cautious about the kind of language used, preferring to focus upon the issue of associative autonomy that was constantly under threat from Salazar's government (Garrido 1996). However, the years that followed saw the gradual development of an anti-regime rhetoric that was concerned with social questions and determined to bury the image of the student body as a kind of self-absorbed corporation. In Coimbra, acts associated to academic rituals (praxe), such as the initiation rites for freshers or 
the use of the academic gown and cassock, began to disappear, giving way to a new type of student who was more interested in opening up to the outside world than in remaining circumscribed by 'traditional Coimbra society' (Lopes 1982).

By the end of the decade, much of the country's youth was irremediably estranged from the ideology of the dictatorship, and had begun to cultivate links with various forms of Marxism instead (Cardina 2008). This change was demonstrated through mass student participation in aid efforts to help the victims of the devastating floods that hit in the south of the country on 25 and 26 November 1967. In the aftermath of the tragedy, the government spoke of a "chain of human solidarity that makes no distinctions of class' and 'the victory of man, whom nature had crushed' (Diário da Manhã, 27 November 1967). However, the students denounced the inertia of the official emergency services, and pointed out that according to data from the Institute of Meteorology, most of the rain had actually fallen on Estoril, although the 500 or more victims were from the shanty towns around Lisbon and the poor areas of the Ribatejo (Solidariedade Estudantil, December 1967).

For many students, this campaign represented the final breach with the Estado Novo. Rita Veiga, evoking in 1997 her participation in this journey, speaks of mud as a 'malignant force' that 'had left behind a smell of organic acid as if it had kept in itself the misery of the sheds it had destroyed' (Melo 1997). She recalls how, for her generation, this was the moment of 'irreparable rupture' with a regime that appeared 'completely cynical' (Melo 1997). João Bernardo, in turn, notes how shocked he was by the appearance of the landlord in the morning following the disaster, 'accompanied by the Republican Guard, to demand the payment of monthly rental' for spaces that the disaster had made uninhabitable (Andringa 1989: episode 3).

At the same time, the campaign had served to establish bonds of trust and recognition amongst the participants. Jorge Wemans, while a student linked to Catholic structures, underlines the enduring effects of the floods:

I remember that after the flood, when we wanted to spread the thesis of the Aveiro Congress, some anti-colonial document, pondering the participation in the elections of ' 69 , organising a holiday campsite, any action or reflection meetings, we'd start by trading names and phone numbers and there came the perennial question, 'But who is this guy, is he trustworthy?', to which we received the inevitable answer, 'Do you not remember? He was there with us during the flood!' Having participated in those days had become sufficient in being accepted.

(Wemans 1997)

This helps explain the absence of organised expressions of jubilation or demonstrations of expectation amongst students when Salazar was replaced as head of government in August 1968 after falling from a chair in his holiday home. His place was taken by Marcelo Caetano, a law professor who had been linked to the Estado Novo from its beginnings, and who had occupied important political positions and helped construct the regime's legal and ideological edifice. In the years immediately preceding 
his appointment as prime minister, Caetano had acquired a certain liberal reputation, particularly after resigning as rector of the University of Lisbon in 1962 following the police invasion of university premises.

Indeed, despite the new period of political hardening that took place in the 1970s, the first two years of Caetano's administration did see the implementation of some measures aimed at 'liberalising, while maintaining the war' (Rosas 1994: 486). Many were merely cosmetic (such as changing the name of the political police and the official party), but there were also more effective gestures. For example, the socialist, Mário Soares, and the bishop of Oporto, António Ferreira Gomes, were allowed to return from exile; new trade union legislation was passed dispensing with the ministerial ratification of their leaders; and the People's National Action party was opened up to new currents (such as a sector that became known as its 'liberal wing', included on the electoral lists of 1969).

It was in this context of slight political decompression that, in Coimbra, a pro-election committee managed to restore elections for the General Directorate of the Coimbra Academic Association (DG/AAC), suspended since 1965 when the leaders of the student association were placed under government-appointed administrative committees. Following a lively campaign, elections were held on 12 February 1969, and resulted in a clear left-wing victory. This naturally opened up the way for a more vigorous confrontation between the students and the authorities.

The tone was set at the opening of the new mathematics department building on 17 April 1969, when hundreds of students gathered at the entrance and demanded to speak, while inside the same request was being made by the president of the DG/AAC, Alberto Martins. Unable to make themselves heard, the demonstrators booed the president of the republic, Américo Tomás, as he was leaving, and decided to hold their own opening ceremony after the officials had all left. During the days that followed some of the student leaders were arrested, which resulted in the unleashing of a powerful solidarity movement that culminated in a boycott of exams that the great majority of students adhered to. This allowed a pedagogical dimension to be included into the student protests. Formal examinations were replaced by free courses, seminars and study meetings, where authors and subjects not included in the university canon were openly discussed.

Thus, during the 'crisis of '69', as the conflict came to be known, types of student protest that were in keeping with a certain Zeitgeist converged with a progressive appropriation of the Coimbra ethos. For example, rituals that could be equated with the traditional praxe (such as the annual ribbon-burning festival, the queima das fitas) were suspended, and a period of academic mourning (luto académico) was formally proclaimed. There were also new forms of contestation that brought together political, cultural and generational elements: the distribution of flowers amongst the local people (operação flor); the letting-off of balloons from a central point in the city (operação balão); the adoption of guerilla-style tactics in clashes with the authorities; and the drawing of humorous cartoons. In 1969, then, the struggle focused mostly upon the democratisation of the education system, pedagogical contestation and criticism of the dictatorship. However, in the following years, the face of student activism was to change considerably as new causes were brought on board. 


\section{Radicalism and fragmentation in the 'end years'}

According to Rui Bebiano (2003b), there were three forms of student movement in Portugal. The first involved the criticism of particular attitudes on the part of the academic authorities and advocated intra-institutional intervention. The second attempted to bring about alterations in government policy in the education sector, and, while remaining focused on the specific domain of education, also sought to direct student action towards intervention at the national level. The third had a much broader agenda, involving intervention in society at large, or the very definition of the regime itself. This last trend, which gradually consolidated throughout the 1960s, became hegemonic between 1969-70 and 1974, as we can see from the politicised interpretations that were made of the new government proposals for education, and the expansion of anti-colonialist and anti-capitalist postures.

In January 1970, when the newly appointed education minister, José Veiga Simão, announced his intention to 'democratise education', he soon discovered this would have to take account of two issues. Firstly, he had to respond immediately to the student unrest, which in Coimbra involved appointing a new rector, offering an amnesty to those students who were awaiting disciplinary or criminal proceedings and demobilising those who had been punitively enlisted in the armed forces. Secondly, he would have to reform the entire educational system, involving expansion, regionalisation and diversification.

In fact, the new minister had realised that there was a great contradiction at the heart of the university system. For while access to higher education was severely restricted in social terms, the university population had in fact increased by almost 100 per cent during the 1960s, due mostly to the emerging middle-class and its expectations of social mobility. Although the most significant increase only took place after the revolution of 25 April 1974, the number of students attending Portuguese universities more than tripled in the space of two decades, from 15,152 in 1950-1 to 49,461 in 1970-1 (Grácio 1989).

It was in this context of the expansion of the education system that the reforms were announced. Before the changes were implemented there were to be public debates involving all agents in the educational system, drawing on such concepts as 'democratisation of education', 'university reform' and 'autonomy, co-management and participation', which seemed at first sight to have come straight out of any student agenda. At the same time, however, Veiga Simão affirmed the need for a 'peaceful, depoliticised' reform that would eschew the temptations of ideological discourse.

In the opinion of Stephen Stoer, there were two possible ways of viewing the Veiga Simão reform prior to 1974 . Either it could be seen as a way of stimulating the economic modernisation of the country within a broader framework of national development and social progress, or it represented a mere reorganisation of resources aimed at satisfying the economic elites rather than solving the political and social crisis (Stoer 1986: 114-5). This was why the newspaper Comércio do Funchal argued in an editorial that 'only a manifest lack of vision could view the new minister's reformist policies as some sort of Trojan horse within the dominant system' (Comércio do Funchal, 5 April 1970). The student movement inclined towards this interpretation. As Santos Simões said, 'the overwhelming 
1. 'I had only one limitation, one that was for me very difficult to manage. It was not the regime; it was the war overseas. That war in some way damaged my attempts at opening up. When this component was finally introduced into the process, it was difficult for me to defend and control, and so set limitations and led to situations that were more complex. Had the students genuinely wanted to restrict their debates to the subject of education, without introducing the overseas war into the process, there was no-one that could stop us from a reform that might have been deeper.' (Teodoro 2001: 289) majority of university students are aware not only that their education system is outdated and decrepit, but also that reform cannot be achieved without a profound shake-up of the whole political, social and economic system' (Simões 1971: 14).

Though the consequences of the apparently interminable colonial war certainly played an important part in this rejection, it would be simplistic to suggest that these were the only reasons for it, as Veiga Simão's words might lead us to think. ${ }^{1}$ For there was also another struggle going on, one that involved the deconstruction of the supposedly apolitical character of the proposed restructuring. Under the mantle of neutrality, the reform ultimately aimed at modernising Portuguese capitalism, and thus cut no ice in a milieu that was increasingly given to politicised readings of society. The democratisation of education was shown to be impractical 'without profound political decisions' and 'without radical change in the relations of production', revealing that 'the education system is not apolitical, just as its teachings and internal life cannot be' (Comércio do Funchal, 31 January 1971).

The colonial question was clearly beginning to take centre stage in student circles. The war waged by the Portuguese state against African independence movements (which had started in Angola during February 1961 before gradually spreading to Guinea-Bissau in January 1963 and Mozambique in August 1964) stirred up feelings of revulsion among the university youth. Even so, until the end of the 1960s explicit contestation remained circumscribed to certain groups that had direct connections to the colonies, such as the Empire Students' House in Lisbon, the Coimbra 'republics' of Kimbo dos Sobas and Mil-Y-Onários, and other belligerent groups from the embryonic extreme left. In February 1968, the antiVietnam demonstration in front of the American Embassy, which aimed to strike at Portuguese colonialism at the same time, illustrated the growing anti-colonial feeling among the youth.

Nevertheless, the war scarcely figured in the catalogue of grievances proclaimed by the student movement in Coimbra, even during the "crisis of '69' (although it was admittedly more developed in Lisbon). This has been recognised in different accounts by Celso Cruzeiro and João Cabral Fernandes. The former, a prominent member of the 1969 association leadership, acknowledged that the problem 'was never properly confronted and articulated by the Coimbra movement' (Cruzeiro 1989: 114-5), while the latter, a member of the Trotskyite minority, noted that, 'in 1969, the structure and lack of democracy in the university was questioned', but that 'any talk of rejecting the colonial war was pure fantasy' (Fernandes 2003).

We should bear in mind that the subject of the war was rarely broached in a critical or undaunted way in any social sphere. A mantle of silence covered 'public opinion, which was misinformed and controlled, remote from African problems, and steeped in the mystique of Empire' (Ribeiro 2004: 174). Cultural values of honour, pride and masculinity also contributed to this attitude, as the writer Fernando Dacosta observed:

If a man did not serve in the army or was dispensed from service, he was seen as somehow inferior, disgraced. It was shameful not to go - young men would lose their girlfriends and reputation if they did that.

(Dacosta 2001: 265) 
The Portuguese military effort in Africa was proportionally greater than that made by any other colonial power, accounting for 'up to 40-50 per cent of total public expenditure' (Barreto 2000: 40). According to Raby, 'the weight of the war in terms of the percentage of men mobilised and victims, relative to the country's population, was greater than the war in Vietnam for the USA' (Raby 1990: 269). Between 1961 and 1974, more than 100,000 young people are estimated to have fled the call-up. Almost every Portuguese boy knew he had to perform at least three years' military service that would be served away from his home community and under conditions of strong physical and psychological risk. By the end of the decade, the pervasive student struggles, the presence of Vietnam in the media and the significant flux of emigration had changed the image of a conflict that seemed set to continue.

With the growing unpopularity of the colonial war, both inside and outside Portugal, and the increasing number of young men who dodged conscription and of deserters, who amounted to over 20 per cent of the total between 1970 and 1972 (Estado-Maior 1988: 258), the government began to use the war as a threat. At that time, misbehaviour became a justification for forced enlistment. However, the regime ended up paying dearly for this strategy, for the result was that in the barracks and on the battlefield, the troops, who were tired of the interminable campaign, became increasingly politicised. As Pedro Pezarat Correia recalls, the experience of living alongside a more engaged strata from the universities led many soldiers to see themselves 'between two Zeca Afonso songs, reflecting together, wondering why they were there, what the war was for and who was benefiting from it?' (Correia 1990: 41).

The anti-colonial and anti-capitalist discourse largely derived from a cluster of small extreme-left groups that were inspired by the international atmosphere of protest that characterised the post-1968 period. New ethical and aesthetic references had emerged in the wake of the Chinese Cultural Revolution, the Cuban revolution and various other armed independence movements. Alternative political icons, such as Ho Chi Minh, Mao Tse Tung and Che Guevara, gained prominence during this period, characterised by a 'fundamentally anti-realist voluntarism', which, in the case of the last two, even went as far as contesting the Soviet norm on ideological, political and cultural grounds (Frank 2000: 36). This led to the emergence of a new confrontational style, involving the promotion of reckless demonstrations, pamphleteering in broad daylight or the stoning of banks.

Despite the fact that many of these organisations were very small, all were intensely involved in stirring up unrest. Some bore the mark of professionalism, with student circles being used for rallying support and as a recruitment ground. Anti-colonial groupings, such as the Committees for Anti-Colonial Struggle (CLAC - Comités de Luta Anti-Colonial), connected to extreme-left organisations and attracted growing numbers of students. The new left-wing discourse rejected both the methods and functions of capitalism and, with marked virulence, traditional organisations made up of 'bureaucrats that are completely divorced from the masses they represent' (Núcleos Sindicais de Base, April 1972). Thus, the PCP, which had been considered reckless in the previous decade for promoting confrontation with 
2. At the start of the academic year 1972-3, almost all student associations were closed or banned. In Oporto, the students' association of the faculty of medicine was closed, and the pro-associative committees in the faculties of economics, engineering and letters, and in the grammar and vocational schools, were outlawed. In Lisbon, the students' associations in law, industry and sciences were closed and the pro-associative committees were outlawed in medicine and pharmacy, and closed in letters and business. In Coimbra, the DG/AAC was closed from February 1971 (Comissão Associativa, 16 November 1972). authorities, was now reclassified as reformist for wanting to focus its protests upon the university instead of questioning the whole basis of capitalist society.

In an attempt to reverse its gradual loss of influence, in January 1972 the PCP created the Union of Communist Students (UEC - União dos Estudantes Comunistas), which was intended to 'strengthen the links' between the party and the student community (UEC, January 1972). Its strategy was essentially to fight for consensual objectives, which allowed it to extend its support base as much as possible. Thus, 'unity' and the 'general democratic reform of education' became its main principles, which meant that, in practice, students from the UEC would often have to take on the delicate task of cooling impulses that threatened the legality of the associations. Despite their common stance in the multifaceted opposition camp, the differences between the PCP and the more extreme-left currents grew more pronounced. One source of dissension was the attitude to be adopted with respect to the colonial war. The majority of the extreme-left groups supported desertion, either immediately or after weapons had been handed out at the end of the training period, while the PCP advised its members to refuse 'individual desertions' and to go as far as possible, including to the battlefields, always with the intention of enlightening other soldiers and persuading them not to fight (O Militante, August 1966).

This new framework, combined with the repression that was now being used against the associations, ${ }^{2}$ led to changes in ways of behaving. The associative movement, based upon structures that were more or less fixed, and grounded in principles such as autonomy and freedom of association, was replaced by more fragmented, voluntarist and radicalised forms of contestation. Untrammelled by representation, the meetings, debates and study groups gradually became part of the new forms of action, while academic cultural groups tended to become politicised (since most students no longer aimed to be an elite disconnected from society). The First International Festival of University Chorus (Primeiro Festival Internacional de Coros Universitários), organised by the traditionalist right-wing group Orfeon Académico de Coimbra, was vigorously boycotted in Oporto by hundreds of students during the Easter of 1973. In Coimbra, after the 'crisis of '69' the DG/AAC suggested that new students should no longer be subjected to hierarchical forms of relationship, and argued that the already weakened vestiges of the 'retrograde perspective of traditional student rituals' should be dropped altogether (Direcção-Geral, 12 November 1970).

Another important phenomenon was the increase in the number of women in higher education during the 1960s as a result of female emancipation. While this was visible throughout the Western world, in Portugal it was due mostly to the mobilisation of men to the war in Africa. Traditional social roles began to be openly contested at this time, and by the start of the 1970s women were noticeably more visible in the struggle against the dictatorship. However, this did not mean that the thesis 'the personal is political', introduced by the second wave of feminism, was given relevant expression. The relationship between genders was perceived essentially as a struggle for equality, and approaches to oppression that went beyond mere class relations were practically unknown. 
Thus, in the final phase of the regime, the student community would no longer negotiate with the authorities, a position that was made irreversible by the killing of José António Ribeiro dos Santos - a law student and member of the Movement for the Reorganisation of the Proletariat Party (MRPP - Movimento Reorganizativo do Partido do Proletariado) - by the regime's secret police (PIDE/DGS - Polícia Internacional de Defesa do Estado/Direcção-Geral de Segurança) on 12 October $1972 .^{3}$ That crime put paid once and for all to the increasingly utopian vision that normality might return to university life, while the combative attitude spread to urban high schools, intensifying up to the fall of the regime (Costa 2002: 30). Indeed, Joaquim Veríssimo Serrão, rector of the University of Lisbon, informed Caetano of this in a letter dated 27 July 1973, in which he worriedly observed that "political unrest in the universities, previously the province of graduates, has become frequent amongst first-year students; now we fear it even in secondary schools, and the fault lies exclusively with those who cannot or will not impose authority' (Antunes 1985: 400).

Despite this, the movement had undoubtedly reached an impasse in the final years of the Estado Novo. On the one hand, intervention was now hampered by the sheer number of organisations that expended much of their energy quarrelling amongst themselves. Their discourse was unable to stir up the masses without bringing about an immediate fracture in student unity. Moreover, the effective politicisation of a youth that now had the colonial war and the shape of the regime at the top of its agenda, combined with the intense repression of the associations, brought about the undoing of the student movement, understood as a unitary movement centred upon the place where it had developed - the university. The unitarist strategy of the UEC, which set up a national coordinating structure the National Union of Portuguese Students (UNEP - União Nacional dos Estudantes Portugueses), remained on the drawing board, clearly demonstrating the ineffectiveness of this line of action.

In general, after the end of the 1960s, with Marcelism unsuccessfully seeking 'renewal within continuity', student intervention became increasingly politicised, turning its attentions beyond the specific domain of education to the very nature of the regime. Issues such as the social utility of knowledge and Portugal's backwardness with regards to the distribution of that knowledge were brought to bear on the debate through processes anchored in a rejection of the authoritarianism of the education system and the state. In the meantime, a new student image was being consolidated an image that incorporated social commitment and reflected the changes that had taken place in the realms of morality, social relationships, politics and culture. This, together with the long drawn-out colonial wars in Africa, was what lay behind the explicit contestation of the regime by the student movement, and its forthright rejection of Portuguese colonialism and all its consequences.

\section{References}

Andringa, D. (1989), Geração de 60, six television programmes, RTP2, 3 August7 September 1992.

Antunes, J. F. (ed.) (1985), Cartas particulares a Marcelo Caetano, 2 vols, Lisbon: Dom Quixote.
3. On that day, an antirepression meeting was to be held in the premises of the College of Economics and Finance (ISCEF). A little before the start of the meeting, the students noticed a police officer in the compound. They seized him and contacted the PIDE/DGS, requesting that they come and identify him as one of their own. When the officers arrived at the lecture hall, they claimed they did not know the individual, but insisted on taking him with them. In the ensuing scuffle, the two policemen present at the site fired their guns, hitting José Lamego and Ribeiro dos Santos, who later died in hospital (Costa 2002; Lourenço, Costa and Pena 2001: 172-5; Madeira, Pimentel and Farinha 2007: 403-10). 
Barreto, A. (ed.) (2000), A situação social em Portugal, 1960-1999, 2 vols, Lisbon: Imprensa de Ciências Sociais.

Bebiano, R. (2003a), O poder da imaginação: Juventude, rebeldia e resistência nos anos 60, Coimbra: Angelus Novus.

— (2003b), 'Cidade e memória na intervenção estudantil em Coimbra', Revista Crítica de Ciências Sociais 66: 151-63.

Berman, P. (2005), Power and the idealists, New York, NY: Soft Skull.

Cardina, M. (2008), A tradição da contestação: Resistência estudantil em Coimbra no marcelismo, Coimbra: Angelus Novus.

Coelho, Z. (ed.) (1973), Maio e a crise da civilização burguesa de António José Saraiva: Textos polémicos de Daniel G. Paulo, Jofre Amaral Nogueira, José Pacheco Pereira, Mário Sottomayor Cardia, Zeferino Coelho, Oporto: J. da Cruz Santos.

Comércio do Funchal (1970), 'Educação: evoluir, continuar', 5 April, no. 2058, p. 2.

— (1971), 'Da actualidade universitária', 31 January, no. 2096, pp. 5-6.

Comissão Associativa (1972), 'Sobre a Tomada da Bastilha. Algumas questões de organização' [leaflet], 16 November.

Correia, P. P. (1990), ‘Capitães de Abril: produto da geração dos anos 60?’ Vértice 26: 40-1.

Costa, J. (2002), 'O ano da morte de Ribeiro Santos', História 49: 24-31.

Cruzeiro, C. (1989), Coimbra 1969: a crise académica o debate de ideias e a prática ontem e hoje, Oporto: Afrontamento.

Cunhal, Á. (1974 [1971]), Radicalismo pequeno-burguês de fachada socialista, 3rd ed., Lisbon: Avante!

Dacosta, F. (2001), Nascido no Estado Novo, Lisbon: Notícias.

Diário da Manhã (1967), 'Ultrapassa 250 mortos o número de vítimas da catástrofe que assolou as terras da Estremadura e do Ribatejo', 27 November 13060: 1.

Direção-Geral [da Associação Académica de Coimbra] (1970), 'Semana da Recepção aos Novos Alunos' [leaflet], 12 November.

Estado-Maior do Exército (1988), Resenha histórico-militar das campanhas de África (1961-1974), vol. 1: Enquadramento geral, Lisbon: Estado-Maior do Exército.

Fernandes, J. C. (2003), 'O fundamental para qualquer acção política é o programa', Combate 276: 6-7.

Frank, R. (2000), 'Imaginaire politique et figures symboliques internationales: Castro, Hô, Mao et le Che', in Dreyfus-Armand, G., Frank, R., Lévy, M.-F. and Zancarini-Fournel, M. (eds), Les années 68: Le temps de la contestation, Paris: Complexe, pp. 31-47.

Gago, M. (1998), 'Ciência e tecnologia para o próximo milénio', Diferencial http:// diferencial.ist.utl.pt/edicao/22/gago.htm. (Accessed 28 September 2008.)

Garrido, Á. (1996), Movimento estudantil e crise do Estado Novo: Coimbra 1962, Coimbra: Minerva.

Grácio, R. (1989), 'A expansão do sistema de ensino e a movimentação estudantil', in Reis, A. (ed.), Portugal contemporâneo (1958-1974), Lisbon: Alfa, pp. 221-58.

Jameson, F. (1984), 'Periodizing the sixties', in Sayres, S. and Stephenson, A. (eds), The sixties without apology, Minneapolis, MN: University of Minnesota Press, pp. 178-209. 
Lopes, A. R. (1982), A sociedade tradicional Coimbrãa: Introdução ao estudo etnoantropológico, Coimbra: np.

Lopes, J. (2007), Entre as brumas da memória: Os católicos portugueses e a ditadura, Oporto: Ambar.

Lourenço, G., Costa J. and Pena, P. (2001), Grandes planos: Oposição estudantil à ditadura, 1956-1974, Lisbon: Âncora.

Madeira, J., Pimentel, I. F. and Farinha, L. (2007), Vítimas de Salazar: Estado Novo e violência política, Lisbon: A Esfera dos Livros.

Marques, F. P. (2005), A praia sob a calçada: Maio de 68 e a 'Geração de 60', Lisbon: Âncora.

Marwick, A. (1998), The sixties: Cultural revolution in Britain, France, Italy and the United States, c. 1958-1974, Oxford: Oxford University Press.

Massada, J. (2002), Vale a pena ser cientista?, Oporto: Campo de Letras.

Melo, A. (1997), 'O aniversário de Ana Lucas', Pública: Revista do Jornal Público, 23 November 1997, no. 79: 54.

Neves, L. C. (2004), António José Saraiva e Óscar Lopes. Correspondência, Lisbon: Gradiva.

Núcleos Sindicais de Base (1972), ‘Por um sindicalismo de tipo novo' [leaflet], 11 April.

Nunes, A. S. (2000), Antologia sociológica, Lisbon: Imprensa de Ciências Sociais.

O Militante, Boletim do Comité Central do Partido Comunista Português (1966), 'Os jovens comunistas e a guerra colonial', August, no. 144: 2, 8.

Raby, D. L. (1990), A resistência antifascista em Portugal, Lisbon: Salamandra.

Rego, S. L. (1971), 'Os cavaleiros teutónicos, afinal, ainda montam a cavalo...', O Tempo e o Modo, April, no. 86: 31-4.

Reis, A. (1974), 'Marcuse: Marx enriquecido', Seara Nova, March, no. 1542: 21-2.

Resende, J. and Vieira, M. M. (1992), 'Subculturas juvenis nas sociedades modernas: Os Hippies e os Yuppies', Revista Crítica de Ciências Sociais 35: 131-47.

Ribeiro, M. C. (2004), Uma história de regressos: Império, guerra colonial e póscolonialismo, Oporto: Afrontamento.

Rodrigues, J. C. (1968), ‘Com o Coral na Holanda', O Badalo: Jornal do Conselho das Repúblicas - Coimbra, March: 6-7.

Rosas, F. (1994), O Estado Novo (1926-1974), Lisbon: Círculo de Leitores/ Estampa.

Santos, B. S. (1996), Pela mão de Alice: O social e o político na pós-modernidade, 5th ed., Oporto: Afrontamento.

Saraiva, A. J. (1970), Maio e a crise da civilização burguesa, Mem-Martins: EuropaAmérica.

Simões, S. (1971), Ensino: projecto de reforma ou reforma do projecto?, Oporto: Razão Actual.

Solidariedade Estudantil, Secretariado Coordenador da Informação e Propaganda (1967), 'Só chuva?', December, no. 2: 1.

Stephens, J. (1998), Anti-disciplinary protest: Sixties radicalism and post-modernism, Cambridge: Cambridge University Press.

Stoer, S. (1986), Educação e mudança social em Portugal, 1970-1980: Uma década de transição, Oporto: Afrontamento.

Teodoro, A. (2001), A construção política da educação: Estado, mudança social e políticas educativas no Portugal contemporâneo, Oporto: Afrontamento. 
UEC (1972), 'Declaração da União dos Estudantes Comunistas' [brochure], January.

Wemans, J. (1997), 'Os miúdos nas cheias', Pública: Revista do Jornal Público, 23 November, no. 79: 56.

\section{Suggested citation}

Cardina, M. (2008), 'On student movements in the decay of the Estado Novo', Portuguese Journal of Social Science 7: 3, pp. 151-164, doi: 10.1386/pjss.7.3.151/1

\section{Contributor details}

Miguel Cardina is an associate researcher in the Centre for Social Studies at the University of Coimbra (CES). He as also been a doctoral candidate in contemporary history at the University of Coimbra since 2006. He is the author of A tradição da contestação: Resistência estudantil em Coimbra no marcelismo, Coimbra: Angelus Novus, 2008.

Contact: Centre for Social Studies of the University of Coimbra, CES - Colégio de S. Jerónimo, Apartado 3087, 3001-401 Coimbra, Portugal.

Tel: 239855570

Fax: 239855589

E-mail: miguelcardina@gmail.com 
Copyright of Portuguese Journal of Social Science is the property of Intellect Ltd. and its content may not be copied or emailed to multiple sites or posted to a listserv without the copyright holder's express written permission. However, users may print, download, or email articles for individual use. 